\title{
THE ROLE OF CYTOLOGICAL METHOD IN THE DIAGNOSIS OF PARAIMPLANT INFLAMMATION AFTER PRIMARY TOTAL KNEE REPLACEMENT
}

\author{
Galashina E.A. ${ }^{1}$, Zhandarova L.F. ${ }^{2}$, Matveeva O.V.1, Bondarenko A.S. ${ }^{2}$, Shpinyak S.P. ${ }^{1}$,
} Ulyanov V.Yu. ${ }^{1}$

${ }^{I}$ Scientific Research Institute of Traumatology, Orthopedics and Neurosurgery, Saratov State Medical University n.a. V.I. Razumovsky, the Ministry of Health of the Russian Federation, Saratov, e-mail: koniuchienko1983@mail.ru;

${ }^{2}$ Saratov State Medical University n.a. V.I. Razumovsky, the Ministry of Health of the Russian Federation, Saratov, email:meduniv@sgmu.ru

Aims.

The aim of the study was to investigate the feasibility of cytological method in the diagnosis of paraimplant inflammation after primary total knee replacement.

Materials and methods.

Cytological punctate preparations and impression smears of para-articular tissue of the knee endoprosthesis area were studied in 20 patients with primary instability of the endoprosthesis components. Aseptic instability was found in 11 patients, and septic instability found in 9. The cell composition of fluid samples and impression smears were studied by counting of at least 100 cells in several fields of view using the immersion lens.

Results.

Cytogramme of the punctates of patients with aseptic instability of the knee joint characterised by the absence of cellular inflammation elements and fibrotic cells, single lymphocytes and synoviocytes were encountered in the impression smears. Two types of cytogrammes were found in patients with septic instability of the knee joint, characterised by changing ratios of the cellular inflammation elements and acute and subacute inflammation consistent with the picture.

Conclusions.

Cytological method is an available, highly effective study that can be used for examination of punctates and impression smears of para-articular tissues of knee endoprosthesis area.

Keywords: cytological study, knee replacement, primary instability of endoprosthesis components, paraimplant inflammation.

\section{INTRODUCTION.}

Knee arthrosis is a common disease associated with pain and disability. In $7.5 \%$ of all cases, patients aged $>55$ suffer knee pain, where X-ray radiography confirms gonarthrosis; in $2 \%$ of all cases, pain is coupled with motor disorders due to the limited function, which is a serious medical, social, and economic concern [1]. Knee replacement is currently one of the most efficient surgeries that helps restore the joint function and improve the quality of the patient's life $[2,3]$. Like any surgery, knee replacement might be followed by a variety of complications, such as paraprosthetic fractures or primary aseptic loosening [4, 5]. However, periprosthetic infection is the gravest complication of primary replacement; its occurrence rate is $0.3 \%$ to $1.5 \%[6,7]$. Early diagnosis is difficult due to the limited sensitivity and specificity of the existing biochemical, serological, and microbiological markers, especially when the infectious inflammation is subclinical and latent. The existing clinical laboratory tests mainly reveal the systemic body response to the infection; however, they cannot describe the locus of infection in the knee. This is why finding a simple and informative method for diagnosing latent periprosthetic infection is an urgent issue. To that end, clinicians use the cytological diagnosis of periprosthetic infection, which helps effectively differentiate the type of inflammation, the specific cellular reactivity, and the duration of inflammation as a typical pathological process $[8,9]$. 
Russian authors have recently published the findings of a number of studies, where they cytologically tested the liquid produced by tapping the paraarticular tissue in major joints [10].

The goal hereof is to study the feasibility of cytological testing for paraimplant inflammation after primary knee replacement.

\section{MATERIALS AND METHODS.}

In 2018, Scientific Research Institute of Traumatology, Orthopedics and Neurosurgery, Saratov State Medical University n.a. V.I. Razumovsky, the Ministry of Health of the Russian Federation had 20 patients with the primary loosening of the knee replacement components: aseptic in $11(55 \%)$ and septic in $9(45 \%)$ cases. Patients were aged $60 \pm 7.5$ on average, 16 women, 4 men.

The study protocol followed guidelines for experimental investigation with human subjects in accordance with the Declaration of Helsinki and was approved by the ethics committee. Written informed consent was obtained from each patient (or official representative) before the study.

Cytological tests were performed on the liquid extracted by paracentesis from the neoplasms around the implant before surgeries, as well as on the smears taken off the paraarticular knee tissue during surgeries. The joint aspirate was centrifuged at $2000 \mathrm{rpm}$ over 10 minutes to obtain the sediment, from which the cytological preparations were made, 5 per patient. Joint aspirate sediments and soft tissues were applied to defatted slides. Leukodif 200 set was used for fixing and staining. The cellular composition was identified by counting at least 100 cells using a Revelation III SkyOptic microscope and a 10×100 immersive lens.

IBM SPSS 20 Statistics was used to process the data. Most of the data did not follow the normal distribution, which is why the non-parametric Mann-Whitney U-test was used for comparison. The significance threshold $\mathrm{p}$ was 0.05 .

RESULTS. Cytological preparations of the paraarticular tissue extracted by paracentesis from patients with aseptic loosening of implant components contained singular lymphocytes (median count of $2(1 ; 2))$, as well as synoviocytes $(0(0 ; 1))$, see Figure 1 . Smears of removed paraarticular tissue contained no fibrous cells but singular blood cells.

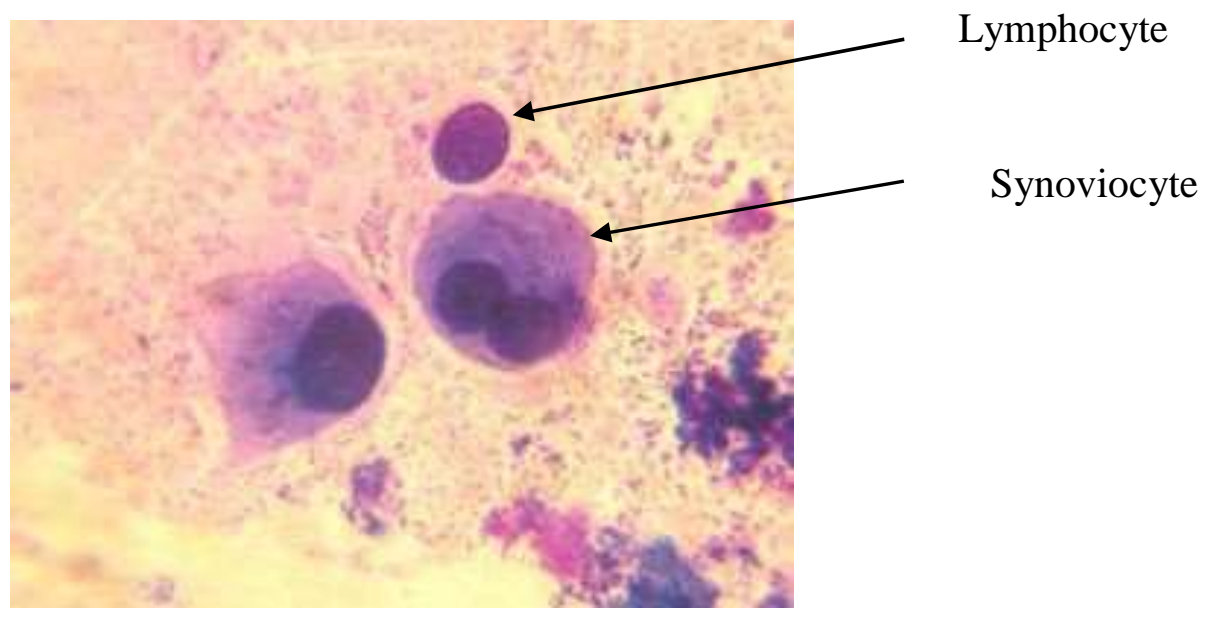

Figure 1. Cytogram of paracentesis-sampled tissue of patients with aseptic knee loosening. 
Two types of cytograms were identified in 9 patients, in whom the loosening was septic.

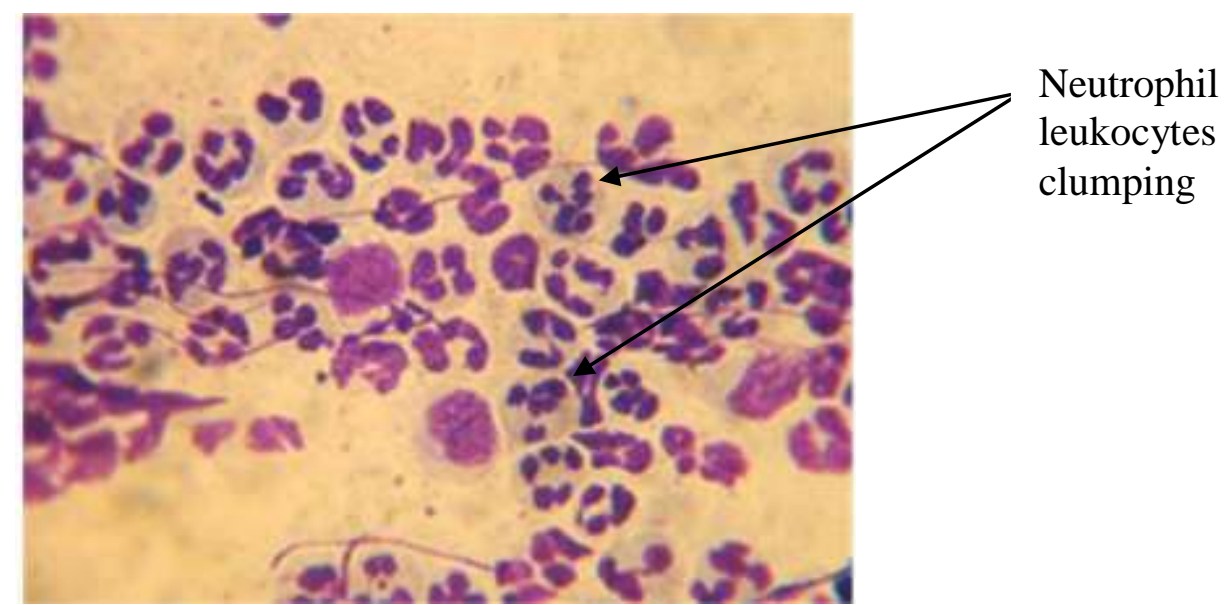

Type 1 matched an acute inflammation, found in $3(15 \%)$ patients. Cytological preparations mainly contained neutrophil leukocytes (median count of $65(62 ; 71)$ ), as well as lymphocytes $(9$ $(8 ; 10))$, macrophages $(1(0 ; 1))$ and histiocytes $(1(0 ; 1)$, see Figure 2.

Figure 2. Cytogram of acutely inflamed tissue sampled from patients with septic knee loosening.

\section{Leukodif 200 staining. Vol. x100}

Type 2 matched subacute inflammation, found in $6(30 \%)$ patients. These preparations contained less neutrophil leukocytes at a median count of 39 (34; 42), more lymphocytes (20 (17; $23)$, histiocytes $(8.5(7 ; 9))$, and macrophages $(6(5 ; 7))$, see Figure 3.

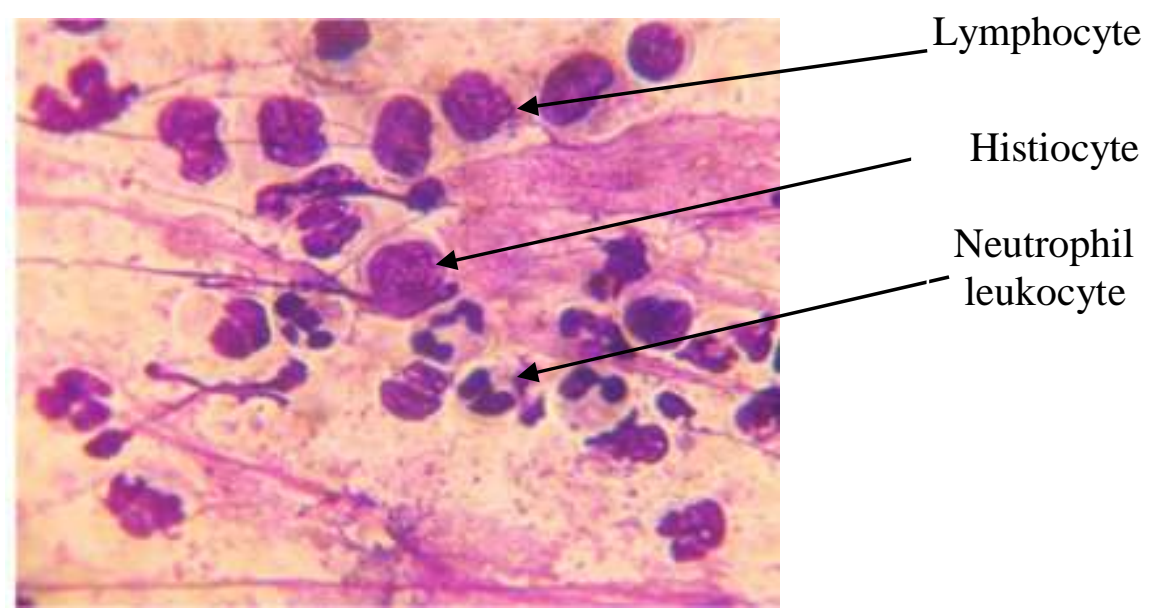

Figure 3. Cytogram of subacutely inflamed tissue sampled from patients with septic knee loosening. Leukodif 200 staining. Vol. x100

Smears of paraarticular tissue removed from these 9 patients contained singular fibrocytes at a median count of $1(0 ; 1)$, see Figure 4 . 


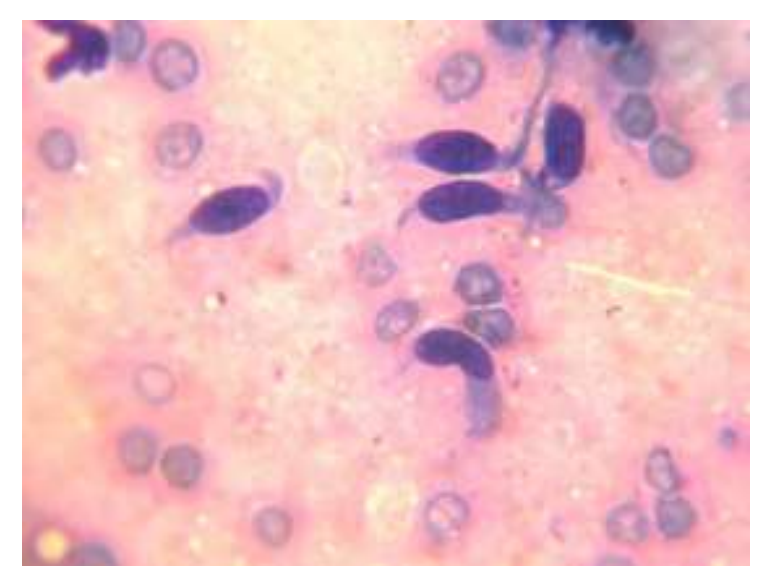

Figure 4. Cytogram of paraarticular tissue smeared from patients with septic knee loosening.

Leukodif 200 staining. Vol. x100

Comparing the septic-vs-aseptic loosening cytograms identified a statistically significant increase in the median counts: $65\left(\mathrm{p}_{1}=3.54 \times 10^{-9}\right)$ more neutrophil leukocytes, $7\left(\mathrm{p}_{1}=3.54 \times 10^{-9}\right)$ more lymphocytes, and singular macrophages $(1(0 ; 1))$ as well as histiocytes $(1(0 ; 1)$ in the former, see Table.

A subacute inflammation cytogram in six other patients had significantly different median counts: 26 leukocytes less $\left(\mathrm{p}_{2}=6.05 \times 10^{-8}\right)$ compared to the acute inflammation, still 39 cells more $\left(\mathrm{p}_{3}=3.29 \times 10^{-14}\right)$ than in patients with aseptic loosening; 11 lymphocytes more $\left(\mathrm{p}_{1}=3.54 \times 10^{-9}\right)$ than in the case of acute inflammation and 18 more $\left(\mathrm{p}_{3}=3.07 \times 10^{-14}\right)$ than in aseptic-loosening patients $\left(\mathrm{p}_{3}=3.07 \times 10^{-14}\right)$.

Notably, the median macrophage count was 5 cells $\left(\mathrm{p}_{2}=6.05 \times 10^{-8}\right)$ higher than in acuteinflammation cytograms and 6 cells higher $\left(\mathrm{p}_{3}=3,29 \times 10^{-14}\right)$ than in aseptic-loosening cytograms; the median histiocyte count was $7.5\left(\mathrm{p}_{2}=6.05 \times 10^{-8}\right)$ higher than in the case of acute inflammation and 8.5 higher than $\left(\mathrm{p}_{3}=3.29 \times 10^{-14}\right)$ in the case of aseptic loosening $\left(\mathrm{p}_{3}=3.29 \times 10^{-14}\right)$.

Cellular inflammation signs in patients with knee loosening after primary knee replacement

\begin{tabular}{|c|c|c|c|}
\hline \multirow{2}{*}{ Cells } & \multicolumn{2}{|c|}{ Primary loosening of the knee implant } \\
\cline { 2 - 4 } & Aseptic, $\mathrm{n}=11$ & \multicolumn{2}{|c|}{ Septic, $\mathrm{n}=9$} \\
\cline { 3 - 4 } & & $\begin{array}{c}\text { Acute inflammation, } \\
\mathrm{n}=3\end{array}$ & $\begin{array}{c}\text { Subacute } \\
\text { inflammation, } \mathrm{n}= \\
6\end{array}$ \\
\hline $\begin{array}{c}\text { Neutrophil } \\
\text { leukocytes }\end{array}$ & $65(62 ; 71)$ & $39(34 ; 42)$ \\
& $0(0 ; 0)$ & $\mathrm{p}_{1}=3.54 \times 10^{-9}$ & $\begin{array}{c}\mathrm{p}_{2}=6.05 \times 10^{-8} \\
\mathrm{p}_{3}=3.29 \times 10^{-14}\end{array}$ \\
\hline Lymphocytes & $2(1 ; 2)$ & $\begin{array}{c}20(17 ; 23) \\
\mathrm{p}_{2}=6.47 \times 10^{-8} \\
\mathrm{p}_{3}=3.07 \times 10^{-14}\end{array}$ \\
\hline Macrophages & & $\mathrm{p}_{1}=3.54 \times 10^{-9}$ & $\begin{array}{c}6(5 ; 7) \\
\mathrm{p}_{2}=6.05 \times 10^{-8} \\
\mathrm{p}_{3}=3.29 \times 10^{-14}\end{array}$ \\
\hline
\end{tabular}




\begin{tabular}{|c|c|c|c|}
\hline Histiocytes & $0(0 ; 0)$ & $\begin{array}{c}1(0 ; 1) \\
\mathrm{p}_{1}>0.05\end{array}$ & $\begin{array}{c}8.5(7 ; 9) \\
\mathrm{p}_{2}=6.05 \times 10^{-8} \\
\mathrm{p}_{3}=3.29 \times 10^{-14}\end{array}$ \\
\hline Synoviocytes & $0(0 ; 1)$ & $0(0 ; 0)$ & $0(0 ; 0)$ \\
& & $\mathrm{p}_{1}>0.05$ & $\mathrm{p}_{2}>0.05$ \\
& & $0(0 ; 1)$ & $1(0 ; 1)$ \\
\hline Fibrocytes & $0(0 ; 0)$ & $\mathrm{p}_{1}>0.05$ & $\mathrm{p}_{2}>0.05$ \\
& & & $\mathrm{p}_{3}>0.05$ \\
\hline
\end{tabular}

The data contain median values (Me), lower quartiles and upper quartiles $(25 \% ; 75 \%)$; $\mathrm{p}$ is the two-sided significance score; $\mathrm{p}_{1}$ is the significance score, acute inflammation vs aseptic loosening; $\mathrm{p}_{1}$ is the significance score, subacute inflammation vs acute inflammation; $\mathrm{p}_{1}$ is the significance score, subacute inflammation vs aseptic loosening

DISCUSSION. The cytological samples of patients with aseptic loosening contained singular synovial cells, a sign of a preserved sufficiently large pool of metabolically active synovium, which is a lining of paraarticular tissue, in which the cellular reactivity is low when there is no inflammation; it is triggered by the particles that appear due to the wear of the friction couples, as well as due to the varying mechanical impact of materials on the residual bone structures and soft tissue.

In the acute-inflammation cytogram in patients with septic knee loosening, neutrophil leukocytes were prevalent, which might be a sign of a protective response to an infectious agent; or a sign of inflammatory activity even if the pathogen cannot be isolated for any reason. Macrophages and histiocytes present in such cytograms were indicative of the inflammation site being confined or the inflammation process becoming chronic [10].

The subacute inflammation cytograms sampled from these patients had greater lymphocyte counts, a sign of proliferation and recovery in the damaged tissue, while lower neutrophil leukocyte counts indicated an active arrest of paraimplant inflammation. Higher macrophage and histiocyte counts indicated a less active subacute inflammation [11].

\section{CONCLUSIONS.}

1. Cytological testing is an affordable and efficient technique for examining the paraarticular tissue sampled around a knee implant.

2. In patients with aseptic loosening of their knee implants, cytological preparations did not show any markers of inflammation, whereas synoviocytes indicated zero inflammation in the paraarticular tissue.

3. Patients with septic loosening had two types of cytograms: acute and subacute inflammation.

\section{FINANCIAL SUPPORT AND SPONSORSHIP}

Nil.

\section{CONFLICTS OF INTEREST}

The authors declare no conflict of interest 


\section{REFERENCES}

1. Matveeva O.V., Zhandarova L.F. Experience of application of morphological methods in diagnosis of inflammatory changes after total endoprosthesis of knee joints [Opyt primeneniia morfologicheskikh metodov $\mathrm{v}$ diagnostike vospalitel'nykh izmenenii posle total'nogo endoprotezirovaniia kolennykh sustavov]. News of Russian clinical cytology - Novosti klinicheskoi tsitologii Rossii, 2015, vol. 19, no. 1, pp. 47-52.

2. Preobrazhenskii P.M., Kazemirskii A.V., Goncharov M.Iu. Current views on diagnosing and treatment of patients with periprosthetic infection after the knee arthroplasty [Sovremennye vzgliady na diagnostiku i lechenie patsientov s periproteznoi infektsiei posle endoprotezirovaniia kolennogo sustava]. Genij Ortopedii - Genij Ortopedii, 2016, no. 3, pp. 94-104. doi: 10.18019/1028-4427-2016-3-94-104

3. Slobodskoi A.B. Risk factors for periprotective infection after large joint endoprosthesis [Faktory riska razvitiia periproteznoi infektsii posle endoprotezirovaniia krupnykh sustavov]. N.N. Priorov Journal of Traumatology and Orthopaedics - Vestnik travmatologii i ortopedii im. N.N. Priorova, 2015, no. 2, pp. 13-18.

4. Ivanov P.P., Kuliaba T.A., Kornilov N.N. et al. To the issue of single-stage knee reendoprosthesis in periprosthetic infection (literature review) [K voprosu ob odnoetapnom reendoprotezirovanii kolennogo sustava pri periproteznoi infektsii (obzor literatury)]. Actual problems of traumatology and orthopaedics. Collection of scientific articles dedicated to the 110th anniversary of R.R. Vreden RNIITO [Aktual'nye problemy travmatologii i ortopedii. Sbornik nauchnykh statei, posviashchennyi 110-letiiu RNIITO im. R.R. Vredena]. St. Petersburg, R.R. Vreden RNIITO, 2016, pp. 74-79.

5. Hanssen A.D., Spangehl M.J. Treatment of the infected hip replacement. Clinical Orthopaedics and Related Research, 2004, vol. 420, pp. 63-71, doi 10.1097/00003086-200403000-00010.

6. Filippenko V.A., Marushchak A.P., Bondarenko S.E. Periprotic infection: diagnosis and treatment. Part 1 (literature review) [Periproteznaia infektsiia: diagnostika i lechenie. Chast' 1 (obzor literatury)]. Orthopaedics, traumatology and prosthetics - Ortopediia, travmatologiia $i$ protezirovanie, 2016, no. 2, pp. 2-7.

7. Voloshin V.P. Place of cytological study in diagnosis and monitoring of periimplantic inflammation of large joints [Mesto tsitologicheskogo issledovaniia $\mathrm{v}$ diagnostike $\mathrm{i}$ monitoringe periimplantarnogo vospaleniia krupnykh sustavov]. N.N. Priorov Journal of Traumatology and Orthopaedics - Vestnik travmatologii i ortopedii im. N.N. Priorova, 2013, no. 1, pp. 58-62.

8. Zakharova N.M., Shatokhina I.S., Voloshin V.P. et al. The features of the local inflammatory reaction in the area of surgical intervention for endoprosthetics of the major vessels [Osobennosti mestnoi vospalitel'noi reaktsii v oblasti khirurgicheskogo vmeshatel'stva pri endoprotezirovanii krupnykh sustavov]. Almanac of Clinical Medicine - Al'manakh klinicheskoi meditsiny, 2012, no. 
27, pp. 14-17.

9. Paukov V.S. Pathological anatomy: textbook in 2 volumes [Patologicheskaia anatomiia: uchebnik v 2 tomakh]. Moscow, GEOTAR-Media, 2016, vol. 1, 728 p.

10. Shabalova I.P., Polonskaia N.Iu. Basics of Clinical Cytological Diagnosis: Tutorial [Osnovy klinicheskoi tsitologicheskoi diagnostiki: uchebnoe posobie]. Moscow, GEOTAR-Media, 2010, 144 p. 